\title{
INDIANA'S FLAWED RELIGIOUS FREEDOM LAW
}

\author{
ROBERT KATZ*
}

\section{INTRODUCTION}

On March 26, 2015, Indiana Governor Mike Pence signed into law Senate Bill 101 ("SB 101"), also known as the Religious Freedom Restoration Act ("RFRA" or the "Act"). Its central provision is that a "governmental entity" may not substantially burden a person's religious exercise unless it demonstrates that imposing that burden on the person would further a compelling governmental interest using the least restrictive means. ${ }^{2}$ The Act provides a framework for balancing government interests with those of religious persons and tilts the scale towards the latter. ${ }^{3}$ It defines the term "governmental entity" to include both government officials and private parties deemed to be "acting under the color of law."

The Act was hugely controversial. Most on this controversy focused on how the Act would affect the interests of lesbian, gay, bisexual, and transgender (LGBT) individuals. ${ }^{5}$ Many expressed concern over the Act's potential impact on local laws designed to protect LGBT individuals from discrimination. ${ }^{6}$ The controversy also drew attention to the fact that Indiana's state-level civil rights law does not ban discrimination based on sexual orientation and gender identity. ${ }^{7}$ The state legislature subsequently enacted Senate Bill 50 ("SB 50"), also known as "the Fix," which provides that the Act may not be used to discriminate against LGBT individuals. ${ }^{8}$

There has been relatively little analysis of what the Act generally requires and how it applies outside the context of anti-discrimination laws. This Article helps fill this gap. Part I examines the Act's basic framework and requirements by illustrating how it would apply to a relatively simple dispute between government officials and persons seeking an exemption from a neutral and generally applicable rule ("rule"). Part II explores the Act's problematic application to

* Professor of Law, Indiana University Robert H. McKinney School of Law. My sincerest gratitude to Mark Sniderman, the librarians and staff of Ruth Lilly Law Library, my exemplary research assistants Ryan Heeb and Heather Kinsler, and the Indiana University Robert H. McKinney School of Law for supporting this work with a summer research stipend. I dedicate this article to the memory of Warren Schwartz.

1. S.B. 101, 119th Gen. Assemb., 1st Reg. Sess. (Ind. 2015) (codified at IND. CodE §§ 3413-9-0.7 to $-11(2015))$.

2. See IND. CODE $§ 34-13-9-8$.

3. Id.

4. Id. § 34-13-9-6.

5. See Stephanie Wang, What the 'Religious Freedom' Law Really Means for Indiana, INDIANAPOLIS STAR (Apr. 3, 2015, 11:13 AM), http://www.indystar.com/story/news/politics/ 2015/03/29/religious-freedom-law-really-means-indiana/70601584/[http://perma.cc/K7N4-JMKQ].

6. $I d$.

7. See generally IND. CODE $\S \S 22-9-1-1$ to -10-15 (2015).

8. S.B. 50, 119th Gen. Assemb., 1st Reg. Sess. (Ind. 2015).

http://dx.doi.org/10.18060/4806.0060 
litigation involving solely private parties ("private litigation"). It considers different ways the Act may extend its reach to private litigation, including the expansive and complex usage of the term "governmental entity." It shows how the Act's inconsistent use of terminology makes it difficult to understand how it operates in this context. The Act's ultimate effect is to make it harder for parties in private litigation to win lawsuits whose success would substantially burden ("burden") $)^{9}$ an opposing party's exercise. ${ }^{10}$

The Article concludes by arguing that the Act should not apply to private litigation. The Act is best understood as a means to combat the perceived indifference of government officials to how their uniform enforcement of rules may burden some citizens' exercise of religion. The Act is inapt in the context of private litigation where citizens seek to vindicate their personal interests in ways that incidentally burden an opposing party's exercise. It is unfair to task private citizens with demonstrating the government's interest in the success of their otherwise valid and meritorious claims. ${ }^{11}$

\section{An Overview of the Act And Its Application to Disputes Between Government Agencies ANd Religious PERSONS}

This Part examines the Act's central provision, main objectives, and its legal framework for implementing these. It then illustrates how the Act would apply to a relatively simple dispute between government officials and persons who seek an exemption from a rule that allegedly burdens their exercise.

\section{A. The Act's Central Provision and Key Objectives}

The Act restricts the ability of a "governmental entity" ("entity") to burden an individual or organization's exercise of religion ("exercise"). ${ }^{12}$ Such entities typically (but not always) consist of government officials. In this context, the Act prohibits government officials from burdening a person's exercise unless they demonstrate that doing so furthers a compelling governmental interest using the least restrictive means. ${ }^{13}$

The Act's subsection 8(a) provides: "[e]xcept as provided in subsection [8](b), a governmental entity may not substantially burden a person's exercise of religion, even if the burden results from a rule of general applicability." 14 Subsection 8 (b) provides, "A governmental entity may substantially burden a person's exercise of religion only if the governmental entity demonstrates that

9. For convenience, the terms "substantially burden" and "burden" are used interchangeably unless otherwise indicated.

10. But see IND. CODE § 34-13-9-11 (2015) (“This chapter is not intended to, and shall not be construed or interpreted to, create a claim or private cause of action against any private employer by any applicant, employee, or former employee.").

11. Id.

12. See id. § 34-13-9-8.

13. Id.

14. Id. 
application of the burden to the person: (1) is in furtherance of a compelling governmental interest; and (2) is the least restrictive means of furthering that compelling governmental interest." 15

The Act operationalizes its central provision through a legal framework of shifting burdens. ${ }^{16}$ It first requires a person seeking an accommodation of his or her exercise to assert a valid claim under the Act. ${ }^{17}$ If the court determines that an entity substantially burdens the person's exercise (or is likely to do so), the entity is presumed to violate the Act. ${ }^{18}$ At this point, the entity is obliged to justify this burden by making the demonstration that subsection 8 (b) requires. ${ }^{19}$ If the entity fails to make this demonstration, the presumption that it violated the Act becomes conclusive. $^{20}$

The Act resembles the federal RFRA, ${ }^{21}$ which Congress famously enacted in response to the United States Supreme Court's 1990 decision in Employment Division v. Smith.$^{22}$ Smith, a member of the Native American Church, was fired from his job with a private drug rehabilitation organization for using peyote as part of a religious ceremony. ${ }^{23}$ Oregon law prohibited possession of peyote under its Uniform Controlled Substances Act. ${ }^{24}$ Smith's unemployment compensation benefits claim was denied on the grounds that he was terminated for work-related misconduct by violating the Controlled Substances Act. ${ }^{25}$ Smith challenged the state agency's decision by asserting that Oregon's prohibition of the use of peyote in a religious ceremony violated the Free Exercise Clause. ${ }^{26}$ The Supreme Court affirmed the agency's decision, reasoning that Oregon's prohibition of peyote was permissible under the Free Exercise Clause, as it applied to all citizens equally, regardless of religious belief, and was not designed to impede upon Smith's religious practices. ${ }^{27}$

The federal RFRA was intended to replace Supreme Court's Free Exercise Clause jurisprudence that $\mathrm{Smith}$ allegedly displaced - that governments could not substantially burden religious exercise without compelling justification. ${ }^{28}$ In an influential letter to Indiana state legislators, a group of prominent scholars who supported SB 101 described the bill as "part of a nationwide response to

15. $I d$.

16. Id. § 34-13-9-10.

17. Id. § 34-13-9-9.

18. Id. $\S 34-13-9-10$ (a).

19. Id. § 34-13-9-8(b).

20. Id. § 34-13-9-10(a).

21. 42 U.S.C. $\S \S 2000$ bb to $2000 b b-4$ (2012).

22. 494 U.S. 872 (1990).

23. Id. at 874 .

24. Id.

25. Id.

26. $I d$.

27. Id. at 876-90.

28. 42 U.S.C. $\S \S 2000 b b-1$ (2012). 
[Smith]." ${ }^{29}$ The lead author of this letter, Professor Douglas Laycock of the University of Virginia School of Law, wrote:

The message that some government officials take from Employment Division v. Smith is that they have no obligation to make any religious exceptions, and that they don't even have to talk to religious groups or individuals seeking exceptions. By clearly telling state and local officials that they have to consider burdens on the exercise of religion, a state RFRA opens the door for discussion. These issues can often be worked out informally if people will just talk to each other in good faith. The Indiana Religious Freedom Restoration Act would help make that happen. ${ }^{30}$

Indiana's Act goes beyond the federal RFRA in its drafters' efforts to apply the Act to private litigation-a feature that distinguishes it from the federal RFRA and state-level religious freedom statutes that apply to public agencies only. ${ }^{31}$ The narrower scope of other religious freedom statutes is typified by New Mexico Supreme Court's 2013 decision in Elane Photography, LLC v. Willock. ${ }^{32}$ In Elane Photography, a same-sex couple sued a wedding photography business for refusing to photograph their commitment ceremony. ${ }^{33}$ The New Mexico Supreme Court found that the business's refusal to serve the couple violated the New Mexico Human Rights Act, which prohibits public accommodations from discriminating against people on the basis of sexual orientation. ${ }^{34}$

Critically, the business argued that its refusal was protected by New Mexico's RFRA, which provides that "a government agency shall not restrict a person's free exercise of religion" absent justification. ${ }^{35}$ The New Mexico Supreme Court rejected this claim on grounds that the state RFRA "is inapplicable to disputes in which a government agency is not a party." ${ }^{36}$ It rejected the contention that a "government agency" was effectively a party to this dispute by virtue of the fact that two state tribunals- the New Mexico Human Rights Commission and a New

29. Letter from Douglas Laycock, Professor of Law, Univ. of Va. Sch. of Law, and co-signed by fifteen colleagues, supporting SB 101 to Ind. Senate Judiciary Comm. (Feb. 3, 2015), available at http://www.indianasenaterepublicans.com/clientuploads/Documents/Professors'\%20Letter\% 20Supporting\%20Religious\%20Freedom\%20Restoration\%20Act.pdf [http://perma.cc/R36YWYEH].

30. Id. at 4.

31. See, e.g., 42 U.S.C. $\$ 2000 \mathrm{bb}-2$ (1) (2012) (“[T]he term `government` includes a branch, department, agency, instrumentality, and official (or other person acting under color of law) of the United States, or of a covered entity."); id. at 2000bb-2(2) (“[T]he term `covered entity` means the District of Columbia, the Commonwealth of Puerto Rico, and each territory and possession of the United States.”).

32. 309 P.3d 53 (N.M. 2013).

33. Id. at 60 .

34. Id. at 59 .

35. Id. at 76 (citing N.M. STAT. ANN. § 28-22-3 (2015)).

36. Id. at 77 . 
Mexico district court-adjudicated the case. ${ }^{37}$

Professor Laycock's letter criticized the New Mexico Supreme Court's holding that, in his words, "its state RFRA does not even apply when the objector has been sued by a private citizen." 38 That holding, he argued, "was almost certainly a mistake" and one that the SB 101 avoided, as "the proposed Indiana legislation makes it clear that the Indiana RFRA would indeed apply in these circumstances. ${ }^{\prime 39}$ Indiana's RFRA may apply to private litigation, as explained in Part II, because it uses the term "governmental entity" (as opposed to "[a] government" as in the federal RFRA, or a "government agency" as in New Mexico's RFRA), which it defines to include private parties acting under the color of law. ${ }^{40}$

\section{B. What Is a "Governmental Entity" and How Can It Burden a Religious Exercise?}

The Act does not restrict the ability of any party to burden his or her exercise. ${ }^{41}$ Rather, it restricts only the ability of a "governmental entity" to do so. ${ }^{42}$ For any alleged burden, therefore, the analysis starts by asking which "governmental entity," if any, has imposed or is likely to impose it. This threshold question is challenging because the Act uses the term "governmental entity" to refer to at least two types of actors. Section 6 provides that "[a]s used in this [Act], 'governmental entity' includes the whole or any part of a branch, department, agency, instrumentality, official, or other individual or entity acting under color of law of any .... (1) [s]tate government [or] (2) [a] political subdivision." 43

The term "governmental entity" may thus denote a government agency or official, i.e., "the whole or any part of a branch, department, agency, instrumentality, official... of any... (1) [s] tate government [or] (2) [a] political subdivision [("Type 1 Entity")]." ${ }^{44}$ Note that by its terms, this provision includes courts and administrative tribunals, which are parts of the judicial or executive branches of government.

The term "governmental entity" may also denote a private party insofar as it

37. $I d$

38. Letter from Douglas Laycock, supra note 29.

39. Id.

40. IND. CODE $§ 34-13-9-6$ (2015).

41. Id. §34-13-9-8(a).

42. Id.

43. Id. § 34-13-9-6 ("As used in this chapter, 'governmental entity' includes the whole or any part of a branch, department, agency, instrumentality, official, or other individual or entity acting under color of law of any of the following: (1) State government. (2) A political subdivision (as defined in IC 36-1-2-13). (3) An instrumentality of a governmental entity described in subdivision (1) or (2), including a state educational institution, a body politic, a body corporate and politic, or any other similar entity established by law.”).

44. Id. (emphasis added). 
acts under the color of state or local law, i.e., "other individual or entity acting under color of law of any.... (1) [s] tate government [or] (2) [a] political subdivision [("Type 2 entity")]." ${ }^{45}$ In a critical omission, the Act does not state when a private party is deemed to be acting under the color of law and thus a "governmental entity" under the Act. As explained in Part II, the Act's failure to define a Type 2 "governmental entity" makes it difficult to understand how the Act applies in the context of private litigation.

An entity may burden the exercise of religion by applying a rule to a religious party in a way that interferes with its exercise. This conclusion derives from the Act's subsection 8(a) and section 1. As noted above, subsection 8(a) provides, in part, that "a governmental entity may not substantially burden a person's exercise of religion, even if the burden results from a rule of general applicability." Although the Act does not define "rule of general applicability," section 1 states that it applies to "all governmental entity statutes, ordinances, resolutions, executive or administrative orders, regulations, customs, and usages." ${ }^{47}$ Section 1 also states that the Act applies to all governmental entity statutes and ordinances "including the implementation or application thereof." ${ }^{8}$

\section{A "Garden Variety" RFRA Case}

Most RFRA cases involve a dispute between government officials and a religious individual or organization. ${ }^{49}$ The following hypothetical offers an example of such a dispute. The City of West Bend enacts an ordinance ("Ordinance") authorizing the City Attorney to bring lawsuits before the local Zoning Tribunal ("Tribunal") to condemn private property. Invoking the Ordinance, the City Attorney files a lawsuit in the Tribunal to condemn property owned by the Church of Ethical Theism ("Church"), a nonprofit corporation, which uses it to hold worship services and run a food pantry. The City Attorney

45. Id. (emphasis added).

46. Id. § 34-13-9-8(a) (emphasis added). Rules of general applicability typically apply to entire categories of people or activities and do not expressly exempt any subcategories from their scope. See Robert W. Hamilton, Procedures for the Adoption of Rules of General Applicability: The Need for Procedural Innovation in Administrative Rulemaking, 60 CAL. L. REV. 1276, 1276 n.1 (1972) ("A rule establishing certain safety standards for uranium mines is a rule of general applicability even though it may affect only a few mines. A rule requiring American Telephone \& Telegraph Co. to provide certain service in the future is a rule of particular applicability.").

47. IND. CODE $\S 34-13-9-1$ ("[The Act] applies to all governmental entity statutes, ordinances, resolutions, executive or administrative orders, regulations, customs, and usages, including the implementation or application thereof, regardless of whether they were enacted, adopted, or initiated before, on, or after July 1, 2015."); see also id. § 34-13-9-2 (providing that such statutes and ordinances "may not be construed to be exempt from the application of this chapter unless a state statute expressly exempts the statute, ordinance, resolution . . . from the application of this chapter by citation to this chapter").

48. Id. (emphasis added).

49. Letter from Douglas Laycock, supra note 29. 
files a similar lawsuit regarding property owned by the Society for Ethical Atheism ("Society"), also a nonprofit corporation, which uses it to hold discussions of ethical issues from an atheistic perspective and run a soup kitchen.

The Act applies to this litigation. The City Attorney is a classic Type 1 "governmental entity." The Church is a "person," which the Act defines to include "[a]n organization, a religious society, a church, a body of communicants, or a group organized and operated primarily for religious purposes." ${ }^{.0}$ The Society may also be a "person" under the Act, which does not define "religion" or "religious." A court might interpret these terms to include nonprofit entities that resemble churches in organization and operation, but whose creeds are not grounded in the belief in a deity.

The City Attorney seeks to apply the Ordinance, a rule, to the Church in a manner that would interfere with its core activities. What is the connection between the Church's exercise and its occupancy of this specific property? The Act does not define "exercise of religion" except to say that it includes "any exercise of religion, whether or not compelled by, or central to, a system of religious belief." ${ }^{51}$ This formulation suggests that the archetypal exercise is an act or refusal to act that is compelled by one's religious belief. Interpretive guidance may be sought here from Senate Bill 568 ("SB 568"), an alternative RFRA bill introduced in the Indiana Senate around the same time as SB 101, but not enacted. SB 568 defines an "exercise of religion" as "the practice or observance of religion," $" 52$ including "a person's ability to . . . act . . or refuse to act, in a manner that is substantially motivated by the person's sincerely held religious belief, regardless of whether the religious belief is compulsory or central to a larger system of religious belief., ${ }^{, 53}$

If the lawsuit succeeds, the Church will have to relocate. Would this burden the Church's exercise within the meaning of the Act? The Act does not define the term "burden" or explain how the government can burden (substantially or otherwise) a person's exercise. ${ }^{54}$ Interpretive guidance might again be sought from SB 568, which uses the term "burden" to mean, inter alia, "an action that directly or indirectly: (1) constrains, inhibits, curtails, or denies the exercise of religion by a person. ${ }^{, 55}$ Forcing the Church to relocate would inhibit its ability to hold religious services and operate a food pantry, at least in the short term. It would likely alter the composition of its members and beneficiaries.

Assuming relocation would burden the Church's exercise, would such burden be "substantial"? Does the qualifier, "substantial," do any work? For example, does it weed out only burdens on exercise that are "trivial, technical, or de minimus" ${ }^{56}$ The Act does not say, thus leaving courts to work out its meaning

50. IND. CODE $§ 34-13-9-7$ (2015).

51. Id. § 34-13-9-5.

52. S.B. 568, 119th Leg., 1st Reg. Sess. (Ind. 2015).

53. Id. (emphasis added).

54. IND. CODE $\S 34-13-9-8(a)$.

55. Ind. S.B. 568.

56. See Christopher C. Lund, Religious Liberty After Gonzales: A Look at State RFRAs, 55 
on a case-by-case basis.

\section{The Act's Burden-Shifting Analysis of a RFRA Claim}

The Church objects to the proposed condemnation, which it believes would burden its exercise. It asks the City Attorney to refrain from using the lawful power conferred by the Ordinance to condemn its property. After the City Attorney refuses, the Church consults the Act's section 9, which provides in part that " [a] person whose exercise of religion has been substantially burdened, or is likely to be substantially burdened, by a violation ... [of the Act] may assert the violation or impending violation as a claim or defense in a judicial or administrative proceeding. ${ }^{, 57}$ The Church claims the prospective burdening would violate the Act because its author, the City Attorney, is a "governmental entity." The Church asserts the alleged impending violation as an affirmative defense to the condemnation lawsuit. ${ }^{58}$ (this Article refers to this as raising a "RFRA defense.")

The Act's section 10 lays out the framework for what happens next. Subsection 10(a) provides that:

If a court or other tribunal in which a violation [of the Act] is asserted in conformity with section $9 \ldots$ determines that: (1) the person's exercise of religion has been substantially burdened, or is likely to be substantially burdened; and (2) the governmental entity imposing the burden has not demonstrated that application of the burden to the person: (A) is in furtherance of a compelling governmental interest; and (B) is the least restrictive means of furthering that compelling governmental interest; the court or other tribunal shall allow a defense against any party and shall grant appropriate relief against the governmental entity. ${ }^{59}$

Subsection 10(a) directs a court to ascertain whether a party invoking the Act (a "RFRA claimant") has asserted a valid RFRA claim, i.e., whether it is "in conformity with section 9" of the Act ${ }^{60}{ }^{0}$ Next, the court assesses the substance of the claimant's claim, i.e., it "determines that ... the person's exercise of religion

S.D. L. REv. 466, 478 (2010) (discussing ARIZ. REv. StAT. ANN. § 41-1493.01(E) (2015) ("In this section, the term substantially burden is intended solely to ensure that this article is not triggered by trivial, technical or de minimis infractions”); IDAHO CODE § 73-402(5) (2015) (including the same exact quoted language)).

57. IND. CODE § 34-13-9-9. Curiously, this passage refers to "a violation of the Act" but omits mention of the violator - a governmental entity. The significance of this omission is discussed below. See infra Part II.

58. Defense, Black's Law Dictionary (10th ed. 2014) (“[F]acts and arguments that, if true, will defeat the plaintiff's or prosecution's claim, even if all the allegations in the complaint are true.").

59. IND. CODE § 34-13-9-10 (2015).

60. Id. 
has been substantially burdened, or is likely to be substantially burdened." ${ }^{61}$ If so, the court presumes the entity has either violated the Act, caused it to be violated, or that such a violation is impending. ${ }^{62}$ The court then determines whether "the governmental entity imposing the burden" has rebutted the presumptive violation by demonstrating a compelling reason for the burdening. ${ }^{63}$

In this hypothetical, the Tribunal ascertains the validity of the Church's RFRA defense to the condemnation lawsuit, i.e., whether it "is asserted in conformity with section 9." ${ }^{\prime 64}$ The Tribunal next considers the substance of the Church's allegation that the lawsuit is likely to substantially burden its exercise. If it determines this to be so, the City Attorney must demonstrate that the proposed condemnation furthers a compelling government interest using the least restrictive means. If the Tribunal concludes that the City Attorney failed to demonstrate this, it must find or "determine" that the proposed condemnation would violate the Act. ${ }^{65}$

\section{E. A Governmental Entity's Legal Burden Is More Demanding than a RFRA Claimant's Legal Burden}

In adjusting the balance between governmental interests and exercise of religion, the Act puts a thumb on the scale in favor of the latter. This adjustment is evident in how the Act allocates legal burdens between a "governmental entity" and a RFRA claimant.

How does the Tribunal determine whether a party's invocation of the Act "is asserted in conformity with section 9" ${ }^{66}$ Must a RFRA claimant do more than simply allege that the other party is a "governmental entity" that has or is likely to substantially burden its exercise of religion? If so, the Act does not indicate what this "more" is.

Once the RFRA claimant establishes a presumptive violation of the Act, the court then determines whether the governmental entity imposing the burden "demonstrated that application of the burden to the person" serves a compelling governmental interest using the least restrictive means. ${ }^{67}$ The Act defines the term "demonstrates" to mean "meets the burdens of going forward with the evidence and of persuasion." 68 The first of these-the burden "of going forward with the evidence"-is also known as the "burden of production." party's "duty to introduce enough evidence on an issue to have the issue decided by the fact-finder, rather than decided against the party in a peremptory ruling
61. Id.
62. Id.
63. Id.
64. Id.
65. Id.
66. Id.
67. Id.
68. Id. § 34-13-9-4.
69. Id.; Burden of Production, BLACK's LAW DiCTIONARY (10th ed. 2014). 
such as a summary judgment or a directed verdict." ${ }^{70}$ The governmental entity's second burden - the burden of persuasion-is "[a] party's duty to convince the fact-finder to view the facts in a way that favors that party."

The Act only uses the words "demonstrates," "evidence," and "persuasion" in defining what a governmental entity must do to rebut a presumptive RFRA violation. ${ }^{72}$ The fact that the Act does not expressly require a RFRA claimant to submit evidence or persuade a court suggests the slightness of its legal burden. ${ }^{73}$

\section{F. The Forms of Relief Available Against the "Governmental Entity" That Violates the Act or Is Likely to Do So}

Subsection 10(a) provides that if the court determines a "violation of [the Act]" has occurred, it "shall allow a defense against any party." "74 It also provides that the court "shall grant appropriate relief against the governmental entity," imposing the burden on the person in violation of the Act. ${ }^{75}$ This formulation suggests that the terms "any party" and "the governmental entity" may refer to two distinct entities. Because the typical RFRA case involves only two parties-government officials and a person raising a RFRA defense-the term "any party" would seem to refer to none other than the government officials allegedly burdening the person's exercise.

Subsections 10 (b) and 10(c) elaborate on the relief available to the prevailing RFRA claimant. ${ }^{76}$ Subsection 10(b) provides that "[r]elief against the governmental entity may include any of the following: (1) Declaratory relief or an injunction or mandate that prevents, restrains, corrects, or abates the violation of this [Act]. (2) Compensatory damages." the appropriate case, the court or other tribunal also may award all or part of the costs of litigation, including reasonable attorney's fees, to a person that prevails against the governmental entity under this [Act]." ${ }^{, 78}$

In the earlier hypothetical, if the Tribunal determines the proposed condemnation of the Church's property would likely violate the Act, the Church would win the suit and the condemnation of the property would be prevented. Yet the Tribunal could also award the Church declaratory or injunctive relief and require the City to compensate the Church and pay its litigation costs.

70. Burden of Production, BLACK’s LAW Dictionary (10th ed. 2014).

71. Id.

72. IND. CODE $\S \S 34-13-9-4,-10$.

73. See Expressio Unius Est Exclusio Alterius, Black's Law Dictionary (10th ed. 2014) (defining the term as a canon of statutory interpretation, which holds "that to express or include one thing implies the exclusion of the other, or of the alternative").

74. IND. CODE § 34-13-9-10 (emphasis added).

75. Id.

76. Id.

77. Id.

78. Id. 


\section{The Act’s Problematic Application to Private Litigation}

This Part examines the Act's application to litigation involving disputes solely between private parties. Professor Laycock claimed that SB 101 "makes it clear that the Indiana RFRA would indeed apply" to cases such as Elane Photography, in which a private citizen's successful lawsuit against a business burdened the latter's exercise of religion. ${ }^{79}$ In truth, as this part demonstrates, the legal path whereby the Act extends its reach to private litigation is far from clear. There are two possibilities. First, the Act could be read to apply to private litigation by declaring a citizen to be acting under the color of law, and thus a "governmental entity" under the Act, when he or she brings a lawsuit that would substantially burden an opposing party's religious exercise. Alternatively, the Act could be read to apply to private litigation even if neither party is a "governmental entity," where a third party "governmental entity" burdens or is likely to burden one of the litigant's exercise. Because the Act extends its reach to private litigation through unusual and opaque terminology that it uses inconsistently, it is difficult to understand how it operates in this context. Whichever path one takes, however, the end result is the same-the Act makes it difficult for a citizen's lawsuit to prevail if its success would impose or effect the imposition of a substantial burden on an opposing party's exercise of religion. Whether the citizen or his or her lawsuit constitutes a "governmental entity" under the Act seems a side issue.

The Act might apply to private litigation because it defines the term "governmental entity" to include not only government officials, but also private parties deemed to be acting under the color of state or local law-a Type 1 and a Type 2 entity, respectively. ${ }^{80}$ The Act's section 9 makes its application to private litigation explicit: a party may raise a RFRA defense in a proceeding "regardless of whether the state or any other governmental entity is a party to the proceeding." 81

Much of the uncertainty over how the Act would apply to private litigation originates in section 9, whose ambiguities are difficult to dispel even upon multiple readings. Section 9 contains two sentences and the first sentence contains two clauses. For convenience, this Article refers to each clause separately. Section 9 provides that:

[First Clause] A person whose exercise of religion has been substantially burdened, or is likely to be substantially burdened, by a violation of [the Act] may assert the violation or impending violation as a claim or defense in a judicial or administrative proceeding, [Second Clause] regardless of whether the state or any other governmental entity is a party to the proceeding. If the relevant governmental entity is not a party to the proceeding, the governmental entity has an unconditional right to

79. Id.

80. Id. § 34-13-9-6.

81. Id. § 34-13-9-9. 
intervene in order to respond to the person's invocation of this chapter. ${ }^{82}$

The First Clause refers to "a violation" of the Act but does not mention a "governmental entity." Who or what violates the Act (or causes it to be violated?) in the First Clause? As mentioned previously, the Act cannot be violated except by a "governmental entity," 83 which may consist of either a Type 1 entity (a public agency or other governmental official or body) or a Type 2 entity (which includes a private party acting under color of law).$^{84}$ The violator referenced in the First Clause is presumably a Type 1 or Type 2 "governmental entity."

The Second Clause of the first sentence raises doubts about the identity of this violator. It permits a person injured or likely to be injured by "a violation" of the Act to "assert the violation or impending violation as a claim or defense in a judicial or administrative proceeding, regardless of whether the state or any other governmental entity is a party to the proceeding." 85 The state is obviously a Type 1 governmental entity. The phrase "or any other governmental entity" presumably refers to any "governmental entity," be it Type 1 and Type 2 entity. ${ }^{86}$ Does this mean the Act permits a RFRA defense to be raised in private litigation against another party even if that party is not a "governmental entity"? Not necessarily.

Section 9's first sentence may be read to limit the Act's scope to litigation involving a "governmental entity" and thus capable of violating the Act by burdening a party's exercise. ${ }^{87}$ There are at least two ways to find a "governmental entity" in a proceeding where one party's success would burden another party's exercise of religion. First, one could posit that whenever a lawsuit would, if successful, substantially burden another party's exercise of religion, the party bringing the lawsuit is for that reason deemed to be "acting under the color of law" and is thus by definition a "governmental entity" under the Act. On this reading, a Type 1 "governmental entity" is defined by what it is-a part of the government. ${ }^{88}$ A Type 2 "governmental entity," by contrast, is defined by what it does-bringing a lawsuit that, if successful, would substantially burden another party's exercise of religion. If this is the case, then the Act's scope is far broader than it might seem on a first reading. Rather than achieve this scope through complex (if not convoluted) definitions, the Act should forthrightly declare what it sets out to do. Such a declaration might read as follows:

No citizen's lawsuit shall succeed, even if otherwise valid and

82. $I d$.

83. Id. § 34-13-9-1.

84. Id. $\S 34-13-9-6$.

85. Id. $\S 34-13-9-9$ (emphasis added).

86. Id.; see also id. § 34-13-9-6.

87. It is worth noting that the Second Clause does not say that the Act applies to private litigation "regardless of whether a governmental entity is a party to the proceeding." Perhaps the phrase "the state or any other governmental entity" refers only to a subset of governmental entities. Id. § 34-13-9-6.

88. Id. § 34-13-9-9. 
meritorious, if success would impose a substantial burden on the losing party's exercise of religion, even if the government is not a party to the litigation, unless the citizen demonstrates that the lawsuit's success furthers a compelling government interest using the least restrictive means

The Act may apply to private litigation insofar as a court or tribunal constitutes a "governmental entity" under the Act, which is a permissible interpretation of the term. ${ }^{89}$ This means the Act potentially applies to any proceeding in which a court could issue a decision or order authorizing any party-be it a private citizen, public agency, a party to the proceeding, or a third party - to do or refrain from doing something that would substantially burden a litigant's exercise of religion.

This approach resembles that taken by the Supreme Court in its 1948 decision in Shelley v. Kraemer. ${ }^{90}$ In Shelley, property owners asked a state court to exclude the petitioners, African-American citizens, from owning or occupying certain property encumbered with a racially restrictive covenant. The Supreme Court reversed the state court's ruling that the covenant was a valid private agreement whose enforcement did not violate the petitioners' rights under the U.S. Constitution. The Supreme Court held that while "the restrictive agreements standing along cannot be regarded as a violation of any rights guaranteed to petitioners by the Fourteenth Amendment," judicial enforcement of the agreement constituted a "state action" under the Fourteenth Amendment, which denied African Americans their constitutionally protected right to equal protection of the law. ${ }^{91}$ It rejected the claim that, in the Court's words, "judicial enforcement of private agreements covenants does not amount to state action; or, in any event, the participation of the State is so attenuated in character as not to amount to state action within the meaning of the Fourteenth Amendment." 92

Section 9's second sentence affects the foregoing analysis and presents its own challenges. It provides that "[i]f the relevant governmental entity is not a party to the proceeding, the governmental entity has an unconditional right to intervene in order to respond to the person's invocation of this chapter." 93 Assuming "the relevant governmental entity" is a Type 1 entity (the government, agencies, etc.), what makes it relevant to the litigation or justifies its right to intervene? When a citizen brings a cause of action, he or she essentially asks the court to apply or implement a generally applicable rule to a specific situation. Is "the relevant government entity" the government or agency that created the rule that the citizen asks the court to apply? Or is the citizen a bystander and the "entity" the agency that directly seeks to enforce the rule to the party. If there are multiple agencies and officials with varying degrees of relevance to the private

89. See infra note 43 and accompanying text.

90. 68 S. Ct. 836 (1948).

91. Id. at $845-846$.

92. Id. at 842 .

93. IND. CODE § 34-13-9-9 (2015). 
litigation, who or what identifies the relevant (or preeminently relevant) entity? Subsection 10(a) reinforces the impression that the Act may apply to private litigation in which neither party is a "governmental entity." It states that:

If a court or other tribunal in which a violation" of the Act is validly asserted ... determines that: (1) the person's exercise of religion has been substantially burdened, or is likely to be substantially burdened; and (2) the governmental entity imposing the burden has not demonstrated that application of the burden to the person: (A) is in furtherance of a compelling governmental interest; and (B) is the least restrictive means of furthering that compelling governmental interest; the court or other tribunal shall allow a defense against any party and shall grant appropriate relief against the governmental entity. ${ }^{94}$

This passage implies a distinction between "any party," which presumably includes a citizen bringing a lawsuit in a private litigation, and "the governmental entity imposing the burden" on a party in that proceeding in violation of the Act. It suggests that: (a) in private litigation where neither litigant is a "governmental entity," (b) where a third party "governmental entity" has or is likely to burden a litigant's exercise in violation of the Act, then the court shall (c) allow the party whose exercise is (or likely to be) burdened to raise the third party's violation of the Act as a defense to the citizen's lawsuit in the private litigation and (d) grant appropriate relief against the third party governmental entity.

In any event, applying RFRA to private litigation makes it harder for a citizen's lawsuit to succeed where success would burden an opposing party's exercise. In order to succeed, the citizen must first prove the merits of the underlying cause of action (breach of contract, negligence, etc.). Next, the citizen must demonstrate that granting the relief to which he or she is otherwise entitled would not substantially burden the opposing party's exercise. If it would, the citizen must also prove that granting relief furthers a substantial governmental interest using the least restrictive means, notwithstanding the resulting burden to the other party's exercise.

To make the inquiry more concrete, consider the following hypothetical. The City of West Bend enacts an ordinance that permits property in certain neighborhoods to be used for residential purposes only (the Zoning Ordinance). The City also enacts a law (the Enforcement Law) that authorizes interested private parties (in addition to the City Attorney) to bring lawsuits in the Tribunal to enforce the Zoning Ordinance.

The Church buys a piece of property in a neighborhood zoned for residential use only and begins using it to hold worship services and operate a food pantry. The traffic, trash, and noise due to the Church's activities impose significant costs on the next-door neighbor (Neighbor) by reducing the value of his house and his overall quality of life. Neighbor asks the City Attorney to file a lawsuit in the Tribunal to compel the Church to stop using the property for non-residential purposes. The City Attorney declines. Neighbor files his own lawsuit in the 
Tribunal seeking the application of the zoning ordinance to the Church's property. The Church asserts that Neighbor's lawsuit, if successful, would burden its exercise in violation of the Act by forcing it to relocate.

Because the City Attorney (a Type 1 "governmental entity") is also responsible for enforcing the zoning ordinance, she is likely "the relevant governmental entity" within the meaning of Section 9's Third Clause. If the City Attorney intervenes in this litigation, Neighbor's lawsuit is more likely to succeed. Neighbor and City Attorney would divide the labor. Neighbor would undertake to prove that the Church is violating the zoning ordinance. The City Attorney would try to demonstrate that applying the zoning ordinance to the Church (alternatively, decline to exempt the Church from the zoning ordinance's application) furthers a compelling governmental interest using the least restrictive means.

This division of labor seems fairer to Neighbor. Unlike the City Attorney, Neighbor has no abstract interest in the uniform application of the zoning ordinance to all properties in the City; he simply wants to maintain the value of his house and his overall quality of life. Unfortunately for Neighbor, section 9 permits but does not require the City Attorney to intervene in the lawsuit.

Let's change the hypothetical to strengthen its resemblance to Shelley $v$. Kraemer. Assume there is no ordinance restricting the Church's property to residential use. Instead, the Church purchased the property encumbered with a covenant to use the property only as a residence. ${ }^{95}$ Neighbor, who has standing to sue to enforce that covenant, files a lawsuit in the Tribunal. An order enforcing the covenant would burden the Church's exercise of religion. The Church may not invoke RFRA as a defense to Neighbor's lawsuit without identifying a "governmental entity" that violates the Act by burdening its exercise. May such an entity be found? The Tribunal is the only Type 1 "governmental entity" involved in the proceeding. Does the Act bar the Tribunal from enforcing the covenant unless Neighbor can make the requisite demonstration?

Neighbor's lawsuit seeks to effect the implementation or application of a general rule ("valid and lawful covenants shall be enforced") to a specific case. In this sense, Neighbor acts under the color of law, but the same may be said of nearly every party that brings a credible lawsuit. At the end of the day, it seems, if a lawsuit's success would substantially burden an opposing party's religious exercise, it presumptively violates the Act unless Neighbor can make the demonstration the Act demands of "governmental entities."

If Neighbor fails to make the requisite showing under section 10(a), he may lose more than a lawsuit. Section 10(a) provides that if "the governmental entity imposing the burden" on the party's exercise does not make the requisite demonstration, "the court or other tribunal shall allow a defense against any party and shall grant appropriate relief against the governmental entity," including compensatory damages and attorney's fees. ${ }^{96}$ In order for the Act to block

95. Church of Christ v. Metro. Bd. of Zoning Appeals of Marion Cnty., 371 N.E.2d 1331, 1333-35 (Ind. Ct. App. 1978) (discussing such covenants prior to the passage of RFRA).

96. IND. CODE $§ 34-13-9-10$ (a) (2015) (emphasis added). 
enforcement of the residential covenant, some "governmental entity" must be specified. Unfortunately for Neighbor, he is the only plausible candidate for that position.

\section{CONCLUSION}

The Act prohibits "a governmental entity" from substantially burdening a person's exercise absent justification, "even if the burden results from a rule of general applicability." "97 The Act, like the federal RFRA, may combat the perceived indifference of government officials-Type 1 governmental entities-towards the burden their refusal to grant exemptions from rules may have on the exercise of religion. The Act imposes a heavy burden on government officials to justify denying such requests for exemptions.

Although the Act may be sensible when applied to government officials, it is inapt and unfair in the context of litigation between private parties. A private claimant who brings a lawsuit to assert a legal claim bears little resemblance to government officials tasked with applying a general rule to whole classes of persons and situations. It may cost very little to create an occasional exemption for a person's exercise of religion. Even if the social costs of such accommodations are not trivial, the government official who creates such exemptions does not personally bear such costs, which in any event might be widely dispersed across the population.

In private litigation, a citizen may have a great deal personally at stake. The lawsuit asks a court to vindicate the citizen's rights by compelling another party to discharge a legal duty to respect these rights. Oftentimes there will be only winners and losers. If the lawsuit prevails, it may result in a substantial burden person on the losing party's burdens exercise. ${ }^{98}$ The citizen will experience loss if a RFRA claim is permitted to defeat his or her otherwise valid and meritorious lawsuit. How should the losses be allocated between private litigants? Although the Act's proponents clearly want it to apply to private litigation, the Act does not provide clear and direct legal path to that end.

97. Id. $\S 34-13-9-8$.

98. But see id. $\$ 34-13-9-11$ ("This chapter is not intended to, and shall not be construed or interpreted to, create a claim or private cause of action against any private employer by any applicant, employee, or former employee."). 


\section{APPENDIX}

$\underline{\text { Senate Bill 101: }}$

SECTION 1. IC 34-13-9 IS ADDED TO THE INDIANA CODE AS A NEW CHAPTER TO READ AS FOLLOWS [EFFECTIVE JULY 1, 2015]:

Chapter 9. Religious Freedom Restoration

Sec. 1. This chapter applies to all governmental entity statutes, ordinances, resolutions, executive or administrative orders, regulations, customs, and usages, including the implementation or application thereof, regardless of whether they were enacted, adopted, or initiated before, on, or after July 1, 2015 .

Sec. 2. A governmental entity statute, ordinance, resolution, executive or administrative order, regulation, custom, or usage may not be construed to be exempt from the application of this chapter unless a state statute expressly exempts the statute, ordinance, resolution, executive or administrative order, regulation, custom, or usage from the application of this chapter by citation to this chapter.

Sec. 3. (a) The following definitions apply throughout this section:

(1) "Establishment Clause" refers to the part of the First Amendment of the Constitution of the United States or the Constitution of the State of Indiana prohibiting laws respecting the establishment of religion.

(2) "Granting", used with respect to government funding, benefits, or exemptions, does not include the denial of government funding, benefits, or exemptions.

(b) This chapter may not be construed to affect, interpret, or in any way address the Establishment Clause.

(c) Granting government funding, benefits, or exemptions, to the extent permissible under the Establishment Clause, does not constitute a violation of this chapter.

Sec. 4. As used in this chapter, "demonstrates" means meets the burdens of going forward with the evidence and of persuasion.

Sec. 5. As used in this chapter, "exercise of religion" includes any exercise of religion, whether or not compelled by, or central to, a system of religious belief.

Sec. 6. As used in this chapter, "governmental entity" includes the whole or any part of a branch, department, agency, instrumentality, official, or other individual or entity acting under

color of law of any of the following:

(1) State government.

(2) A political subdivision (as defined in IC 36-1-2-13).

(3) An instrumentality of a governmental entity described in subdivision (1) or (2), including a state educational institution, a body politic, a body corporate and politic, or any other similar entity established by law.

Sec. 7. As used in this chapter, "person" includes the following: 
(1) An individual.

(2) An organization, a religious society, a church, a body of communicants, or a group organized and operated primarily for religious purposes.

(3) A partnership, a limited liability company, a corporation, a company, a firm, a society, a joint-stock company, an unincorporated association, or another entity that:

(A) may sue and be sued; and

(B) exercises practices that are compelled or limited by a system of religious belief held by:

(i) an individual; or

(ii) the individuals; who have control and substantial ownership of the entity, regardless of whether the entity is organized and operated for profit or nonprofit purposes.

Sec. 8. (a) Except as provided in subsection (b), a governmental entity may not substantially burden a person's exercise of religion, even if the burden results from a rule of general applicability.

(b) A governmental entity may substantially burden a person's exercise of religion only if the governmental entity demonstrates that application of the burden to the person:

(1) is in furtherance of a compelling governmental interest; and

(2) is the least restrictive means of furthering that compelling governmental interest.

Sec. 9. A person whose exercise of religion has been substantially burdened, or is likely to be substantially burdened, by a violation of this chapter may assert the violation or impending violation as a claim or defense in a judicial or administrative

proceeding, regardless of whether the state or any other governmental entity is a party to the proceeding. If the relevant governmental entity is not a party to the proceeding, the governmental entity has an unconditional right to intervene in order to respond to the person's invocation of this chapter.

Sec. 10. (a) If a court or other tribunal in which a violation of this chapter is asserted in conformity with section 9 of this chapter determines that:

(1) the person's exercise of religion has been substantially burdened, or is likely to be substantially burdened; and (2) the governmental entity imposing the burden has not demonstrated that application of the burden to the person:

(A) is in furtherance of a compelling governmental interest; and (B) is the least restrictive means of furthering that compelling governmental interest; the court or other tribunal shall allow a defense against any party and shall grant appropriate relief against the governmental entity.

(b) Relief against the governmental entity may include any of the 
following:

(1) Declaratory relief or an injunction or mandate that prevents, restrains, corrects, or abates the violation of this chapter.

(2) Compensatory damages.

(c) In the appropriate case, the court or other tribunal also may award all or part of the costs of litigation, including reasonable attorney's fees, to a person that prevails against the governmental entity under this chapter.

Sec. 11. This chapter is not intended to, and shall not be construed or interpreted to, create a claim or private cause of action against any private employer by any applicant, employee, or former employee.

Senate Bill 50:

SECTION 1. IC 34-13-9-0.7 IS ADDED TO THE INDIANA CODE AS A NEW SECTION TO READ AS FOLLOWS [EFFECTIVE JULY 1, 2015]:

Sec. 0.7. This chapter does not:

(1) authorize a provider to refuse to offer or provide services, facilities, use of public accommodations, goods, employment, or housing to any member or members of the general public on the basis of race, color, religion, ancestry, age, national origin, disability, sex, sexual orientation, gender identity, or United States military service;

(2) establish a defense to a civil action or criminal prosecution for refusal by a provider to offer or provide services, facilities, use of public accommodations, goods, employment, or housing to any member or members of the general public on the basis of race, color, religion, ancestry, age, national origin, disability, sex, sexual orientation, gender identity, or United States military service; or (3) negate any rights available under the Constitution of the State of Indiana.

SECTION 2. IC 34-13-9-7.5 IS ADDED TO THE INDIANA CODE AS A NEW SECTION TO READ AS FOLLOWS [EFFECTIVE JULY 1, 2015]:

Sec. 7.5. As used in this chapter, "provider" means one (1) or more individuals, partnerships, associations, organizations, limited liability companies, corporations, and other organized groups of persons. The term does not include:

(1) A church or other nonprofit religious organization or society, including an affiliated school, that is exempt from federal income taxation under 26 U.S.C. 501(a), as amended (excluding any activity that generates unrelated business taxable income (as defined in 26 U.S.C. 512, as amended)). 
(2) A rabbi, priest, preacher, minister, pastor, or designee of a church or other nonprofit religious organization or society when the individual is engaged in a religious or affiliated educational function of the church or other nonprofit religious organization or society. 